5. Постанова Верховного Суду України від 19 лютого 2014 р. у справі № 6-162цс13. URL: http://www.scourt.gov.ua/clients/vsu/vsu.nsf/(documents)/CF2A5FA58DAC2679C2257C920 03A7024.

6. Цивільний кодекс України: Закон України від 16 січня 2003 р. № 435-IV. Офіційний вісник Украӥни. 2003. № 11. Ст. 461. (Із змінами).

7. Постанова Верховного Суду України від 27 квітня 2017 р. у справі № 6-422цс17. URL: http://www.scourt.gov.ua/clients/vsu/vsu.nsf/(documents)/C9EEFE46693C1735C2258122002 AE7D8.

8. Постанова Верховного Суду України від 18 січня 2017 р. у справі № 6-2777цс16. URL: http://www.scourt.gov.ua/clients/vsu/vsu.nsf/(documents)/D141A36494BF6E3FC22580B300 2964D4.

9. Постанова Верховного Суду України від 7 червня 2017 р. у справі № 6-872цс17. URL: http://www.scourt.gov.ua/clients/vsu/vsu.nsf/(documents)/8E715790F097866CC2258146005 A7C84

10. Господарський процесуальний кодекс України в редакції від 6 листопада 1991 р. Відомості Верховної Ради України. 1992. № 6. Ст. 56.

11. Про внесення змін до Господарського процесуального кодексу України, Цивільного процесуального кодексу України, Кодексу адміністративного судочинства України та інших законодавчих актів: Закон України від 3 жовтня 2017 р. № 2147-VIII. Відомості Верховної Ради України. 2017. № 48. Ст. 436.

12. Про затвердження Типового договору оренди землі: Постанова Кабінету Міністрів України від 3 березня 2004 р. № 220. Офіиійний вісник Украӥни. 2004. № 9. Ст. 527. (Із змінами).

13. Про державну реєстрацію речових прав на нерухоме майно та їх обтяжень: Закон України від 1 липня 2004 р. № 1952-IV. Відомості Верховної Ради України. 2004. № 51. Ст. 553. (Із змінами).

УдК 346.6:35.073.53(477)

Д. В. Корчевець

здобувач, провідний юрисконсульт

Донецького національного

університету імені Василя Стуса

\title{
ОГЛЯД ПРАКТИКИ ДОПОРОГОВИХ ЗАКУПІВЕЛЬ З ВИКОРИСТАННЯМ СИСТЕМИ РROZORRO
}

Ключові слова: публічні закупівлі, допорогові закупівлі, електронна система закупівель, система PROZORRO, етапи закупівель.

Сфера державних закупівель завжди вважалась однією з найбільш проблемних та сприятливих для корупційних правопорушень. Кардинальна реформа державних закупівель відбулася в Україні після прийняття нового Закону України «Про публічні закупівлі» (далі - Закон) від 25 грудня 2015 року [1].

Можна стверджувати, що прийняття цього Закону уособило перехід до нового розуміння закупівель: вони перестали бути «державними» на користь «публічних» 3 акцентом, що такі закупівлі проводяться за гроші громадян та їх 
кінцевим бенефіціаром є суспільство. 3 огляду на це Закон містить більше запобіжників до проявів корупції під час здійснення закупівель, основним з яких виступає запровадження електронної системи закупівель.

Публічні закупівлі в обов'язковому порядку здійснюються через систему електронних закупівель PROZORRO, якщо вартість товарів, послуг і робіт дорівнює або перевищує вартість, визначену Законом (абз. 2, 3 ч. 1 ст. 2). Натомість, якщо вартість товарів, послуг і робіт є меншою, то замовники повинні дотримуватися принципів здійснення публічних закупівель, установлених Законом, та можуть використовувати електронну систему закупівель (абз. 4 ч. 1 ст. 2 Закону).

Положення ст. 2 Закону посприяло введенню у практичний обіг понять надпорогових i допорогових закупівель, а також використанню системи електронних закупівель під час останніх. На сьогодні склалась певна практика здійснення допорогових закупівель через систему електронних закупівель PROZORRO, яка має певні переваги і недоліки.

Тому огляд практики допорогових закупівель 3 використанням системи PROZORRO є актуальним, дозволить узагальнити основні проблеми у цій сфері і окреслити шляхи їх вирішення.

Варто почати з того, що здійснення допорогових закупівель через систему PROZORRO (далі - Система) Законом не регулюється. Однак на підставі абз. 4 ч. 1 ст. 2 Закону та абз. 21 п. 12 Порядку функціонування електронної системи закупівель та проведення авторизації електронних майданчиків, затвердженого постановою КМУ від 24 лютого 2016 р. № 166 [2] з метою надання замовнику можливості використання електронної системи закупівлі для відбору постачальника товару (товарів), надавача послуги (послуг) та виконання робіт державне підприємство «Зовнішторгвидав України» наказом від 13 квітня 2016 р. № 35 затвердило Порядок здійснення допорогових закупівель, з подальшими змінами, внесеними наказом від 20 червня 2017 р. № 49 (далі - Порядок № 35) [3].

Розглядаючи цей Порядок, варто відмітити унормованість етапів проведення закупівель 3 характеристикою кожного, встановлення строків у межах етапів, певною мірою регулювання питань скасування закупівлі, усунення порушень, вирішення спорів, і ін.

Першим питанням, яке може виникати в учасників допорогових закупівель, $є$ обов’язковість Порядку № 35. У відповіді на нього варто погодитись 3 консультантом з питань публічних закупівель Я. Дубровою: формально Порядок № 35 не $є$ обов’язковим для виконання замовниками, оскільки цей документ не поширюється на зазначених суб'єктів сфери публічних закупівель, тому що це локальний нормативний акт зазначеного державного підприємства [4]. Водночас потрібно звернути увагу на такі чинники: 1) ДП «Зовнішторгвидав України» перетворено на ДП «ПРОЗОРРО», яке обслуговує систему електронних закупівель PROZORRO; 2) допорогові закупівлі через систему електронних закупівель можуть бути реалізовані тільки у системі PROZORRO, регламент якої в цій частині відповідає положенням Порядку № 35. Отже, фактично положення 
Порядку № 35 розповсюджуються на замовників, які вирішили використати електронну систему закупівель, та учасників цих закупівель.

3 аналізу ч. 1 ст. 2 Закону випливає, що допорогові закупівлі охоплюють товари і послуги, вартість яких менше 200 тис. грн., робіт - 1,5 млн. грн., в окремих сферах господарювання вартість товарів і послуг має бути менше 1 млн. грн., робіт - 5 млн. грн. Варто додати, що згідно 3 п. 6.4 Порядку № 35 очікувана вартість закупівлі не може бути меншою, ніж 3 тис. грн.

Проведення допорогових закупівель через систему PROZORRO передбачає проходження таких етапів: 1) оголошення закупівлі; 2) період уточнень, 3) подання пропозицій; 4) аукціон, 5) кваліфікація, визначення переможця та завершення закупівлі. На практиці називають від п'яти до семи етапів цієї процедури, виділяючи в деяких з вищезазначених етапів самостійні, і вказуючи на певні практичні проблеми їх проходження [5].

Першим етапом проведення процедури допорогових закупівель $\epsilon$ оголошення закупівлі. Між цим етапом та етапом подання пропозицій $\epsilon$ період уточнень. Під час оголошення закупівлі замовник розміщує в Системі інформацію про предмет, очікувану вартість закупівлі, умови договору, порядок і умови проведення закупівлі, строк подання пропозицій, вимоги до учасника та іншу інформацію, яка, на його думку, є необхідною для проведення закупівлі. При визначенні умов закупівлі замовник може вказати нецінові критерії та їхню питому вагу, що сумарно не може перевищувати $30 \%$, якщо має намір застосувати процедуру оцінки за критеріями іншими, ніж ціна.

На перший погляд, таке право замовника виглядає позитивним, проте, насправді, може перетворитися у висунення дискримінаційних умов (або прописування умов під певного Учасника) і створення корупційних ризиків. Це випливає з сукупності таких чинників: право, а не обов'язок, вказати, які аналоги та/або еквіваленти товарів прийматимуться у пропозиціях учасників; право вносити зміни в інформацію та документи щодо оголошеної закупівлі до початку прийому пропозицій; не забезпечений обов'язок відповідати на питання учасників під час періоду уточнень.

Також практика свідчить, що замовники можуть порушувати мінімальні строки періоду уточнень і подання пропозицій, невраховуючи святкові і вихідні дні, ігнорувати питання учасників [5]. Слід звернути увагу, що внесені до Порядку № 35 зміни частково врахували ці недоліки, зокрема, щодо святкових і вихідних днів. Так, тривалість періоду уточнень не може бути менше 1-го робочого дня (якщо очікувана вартість закупівлі від 3 тис. грн. до 50 тис. грн.) та не менше 3-х робочих днів (якщо очікувана вартість перевищує 50 тис. грн.); тривалість періоду подання пропозицій - не менше 1-го робочого дня та не менше 2-х робочих днів, відповідно. Слушною $є$ питання $Є$. Ляшенко щодо технічної можливості завадити порушенню мінімальних строків періоду уточнення і подання пропозицій через внесення змін до самої програми [5].

Варто акцентувати увагу, що згідно з п. 6.4 Порядку № 35 замовник може додатково вимагати забезпечення пропозиції у вигляді гарантії виконання зобов'язань учасника перед замовником. Розмір такого забезпечення у 
грошовому виразі не може перевищувати 0,5 \% від очікуваної вартості закупівлі у разі проведення торгів на закупівлю робіт та $3 \%$ - у разі проведення торгів на закупівлю товарів чи послуг на умовах, визначених документацією. Логічно, що учасникам, які не визнані переможцями аукціону, сума забезпечення повертається, однак у Порядку № 35 це не врегульовано.

Після закінчення строку подання пропозицій розпочинається наступний етап - аукціон. Дату та час аукціону Система визначає автоматично, його проведення повинно відбуватись у робочий день та у робочий час. Порядок проведення аукціону регулюється розділом 8 Порядку № 35. У випадках, якщо пропозицію подав лише один учасник, аукціон не проводиться, Система автоматично присвоює закупівлі статус «Кваліфікація». Якщо не надійшло жодної пропозиції, то Система автоматично присвоює закупівлі статус «Закупівля не відбулася». У такому разі у замовника виникає питання щодо його подальших дій і необхідності оголошувати закупівлю повторно. 3 цього приводу консультант з питань публічних закупівель Я. Дуброва зазначає, що подальші дії замовника залежать від того, як прописано механізм здійснення допорогових закупівель у його внутрішньому локальному нормативно-правовому акті. Якщо відповідних обмежень немає, то замовник може укласти прямий договір. Вона ж наголошує, що сторони можуть укласти прямий договір на суму меншу від оголошеної у системі PROZORRO [4].

У випадках, коли пропозиції надійшли від декількох учасників одразу, проводиться аукціон, який складається 3 трьох раундів, під час яких учасники можуть знизити свою цінову пропозицію на суму, не меншу за крок аукціону відносно своєї попередньої ставки, або залишити свою цінову пропозицію незмінною як упродовж всього аукціону, так i в окремому раунді. Після проведення третього раунду всі пропозиції та підтверджуючі документи учасників автоматично відкриваються, а етап аукціону завершується.

Наступним етапом проведення процедури допорогових закупівель через систему PROZORRO є кваліфікація. На підставі п. 9.1 Порядку № 35 замовник розглядає учасника, який надав за результатами аукціону найнижчу пропозицію, та приймає рішення щодо відповідності його пропозиції вимогам, зазначеним в оголошенні на закупівлю. Якщо пропозиція учасника не відповідає умовам закупівлі, зазначеним в оголошенні, замовник має право на його дискваліфікацію, про що він зобов’язаний опублікувати у Системі скан-копію документа 3 аргументованим рішенням. У цьому випадку Система автоматично визначає наступного учасника аукціону з наступною за величиною ціновою пропозицією, а у разі однакових за величиною цінових пропозицій - поданою раніше, як учасника 3 найкращою пропозицією, яка має розглядатися замовником. Якщо пропозиція учасника відповідає умовам закупівлі, замовник визначає такого учасника переможцем та публікує в Системі скан-копію документа 3 відповідним рішенням. Тоді наступним етапом закупівлі $\epsilon$ підписання договору. Однак, у разі, якщо всі учасники закупівлі були дискваліфіковані, закупівля автоматично переводиться Системою у статус «Закупівля не відбулась». 
Учаснику, який вважає свою дискваліфікацію недостатньо аргументованою, п. 9.2 Порядку № 35 надане право звернутися до замовника 3 вимогою надати додаткову інформацію про причини невідповідності його пропозиції умовам закупівлі. Замовник зобов'язаний надати йому відповідь не пізніше ніж через 3 робочих дні з дня надходження такої вимоги.

Однак, налагодження комунікації між замовником та учасником, своєчасні відповіді на питання учасників, є доволі проблемними. Практичний досвід оскарження допорогових закупівель свідчить про те, що найчастіше замовники ігнорують звернення учасників [6]. При цьому у п. 14.4 Порядку № 35 закріплено, що розгляд вимоги не зупиняе процесу проведення закупівлі, тому після початку аукціону або визначення переможця та присвоєння закупівлі у Системі статусу «Завершена», розгляд звернення втрачає свою актуальність для учасника.

Ha сайті PROZORRO рекомендовано оскаржувати рішення замовника, якщо він виписав умови та характеристики так, що обмежив конкуренцію, і не усунув це самостійно після вимоги; учасника дискваліфікували безпідставно; учасник підозрює, що переможця кваліфікували необгрунтовано (або через некомпетентність замовника, або можлива змова). У цьому разі учасник (користувач Системи) може залишити відгук чи подати звернення про порушення, скориставшись посиланням https://dozorro.org/complaints/below [7].

Фактично, це єдиний, проте зовсім не дієвий спосіб вплинути на замовника. Можна припустити, що порушення замовником положень Порядку № 35 щодо реагування на звернення учасників під час періоду уточнення 3 вимогами про усунення порушення у процесі проведення закупівель або вимогами надати додаткову інформацію про дискваліфікацію обумовлені тим, що допорогова процедура - це закупівля, хід проведення якої не регламентується законодавством України і умови закупівлі самостійно визначаються замовником [6]. Крім того, Порядок № 35 не надає учаснику можливості звернутись до третьої «незацікавленої» особи, яка мала б право перевіряти рішення (дії / бездіяльність) замовника на відповідність вимогам Порядку № 35. Також потрібно констатувати невизначеність відповідальності замовника за порушення вимог Порядку № 35 і можливість учасника відстоювати власні інтереси тільки у судовому порядку.

На практиці вищевикладене може призводити до зловживань, обмеження конкуренції, дискримінації учасників; створювати сприятливі умови для корупційних правопорушень. Також наявні практичні проблеми у застосуванні положень Порядку № 35 ставлять під сумнів дотримання принципів здійснення закупівель, закріплених у ст. 3 Закону і повторених у Порядку № 35, а саме: 1) добросовісна конкуренція серед учасників; максимальна економія та ефективність; відкритість та прозорість на всіх стадіях закупівель; недискримінація учасників; об'єктивна та неупереджена оцінка тендерних пропозицій; запобігання корупційним діям і зловживанням.

Таким чином, викладене дозволяє узагальнити практичні проблеми здійснення допорогових закупівель з використанням системи PROZORRO, зокрема: 
наявність можливості встановлювати дискримінаційні положення та обмежувати конкуренцію; невизначеність долі кочтів, сплачених у якості забезпечення пропозиції учасника; можливість порушення замовником встановлених мінімальних строків на всіх етапах допорогових закупівель; залишення замовником звернень учасників без відповіді.

Серед можливих иляхів подолання изих проблем можна пропонувати, насамперед, врегулювати проведення допорогових закупівель з використанням електронної системи закупівель на законодавчому рівні. При изьому за основу можна взяти чинний Порядок № 35, доповнивщи його положеннями щзодо повернення коштів, сплачених у якості забезпечення пропозицї учасникам, які не визнані переможиями аукціону, з встановленням строків $i$ порядку повернення або зобов'язанням конкретизувати иі питання замовником під час оголошення закупівлі; визначення уповноваженого органу та/або порядку розгляду скарг учасників на рішення, діі//бездіяльність замовника; встановлення відповідальності замовника за порушення вимог проведення допорогових закупівель з використанням електронної системи.

Можна очікувати, що врахування вищезазначених пропозицій на законодавчому рівні сприятиме створенню умов для ефективного функціонування системи допорогових закупівель, підвищенню конкуренції у цій сфері, запобіганню проявам корупції, ефективному використанню державних коштів, та забезпеченню високого рівня прозорості.

1. Про публічні закупівлі: Закон України від 25 грудня 2015 р. № 922-VIII. Вiдомості Верховної Ради України. 2016. № 9. Ст. 89. (Із змінами).

2. Порядок функціонування електронної системи закупівель та проведення авторизації електронних майданчиків: Постанова Кабінету Міністрів України від 24 лютого 2016 р. № 166. Офіиійний вісник України. 2016. № 22. Ст. 855.

3. Про затвердження Порядку здійснення державних закупівель: наказ ДП «Зовнішторгвидав України» від 13 квітня 2016 № 35 (зі змінами). URL: https://education.zakupki. prom.ua/nakaz-35-pro-zatverdzhennya-poryadku-zdiysnennya-doporogovuh-zakupivel/.

4. Дуброва Я. Допорогові закупівлі: від А до Я. Бюджетна бухгалтерія. 2017. № 41. URL: https://i.factor.ua/ukr/journals/bb/2017/november/issue-41/article-31758.html.

5. Ляшенко С. Допорогові закупівлі в системі PROZORRO. Чи все прозоро на PROZORRO? Аналітичне видання «Юрист\&Закон». 2017. Випуск 11. URL: https://artius.com. ua/uk/novini/statti/doporogovi-zakupivli-v-sistemi-prozorro-chi-vse-prozoro-na-prozorro/.

6. Допорогові закупівлі в загальній системі електронних закупівель Prozorro (для використання в роботі розпорядників державних коштів): методичнірекомендації.

7. Сайт PROZORRO. URL: https://prozorro.gov.ua/zahist-uchasnikiv. 